\title{
EFFECT OF FELLED WILDING PINES ON PLANT GROWTH IN HIGH COUNTRY GRASSLANDS
}

\author{
T.S.H. PAUL ${ }^{1}$ and N.J. LEDGARD ${ }^{2}$ \\ ${ }^{1}$ Scion, Private Bag 3020, Rotorua, New Zealand \\ ${ }^{2}$ Scion, PO Box 29237, Fendalton, Christchurch, New Zealand
}

Corresponding author: thomas.paul@scionresearch.com

\begin{abstract}
Wilding conifers are invading grassland and shrubland ecosystems in the New Zealand high country. The felling of wildings is common practice to control such infestations. This research investigated the effects of felled pines on growth and composition of grassland vegetation at $\mathrm{Mt}$ Barker, Canterbury. The vegetation within areas of dead trees, felled in 1998, was compared with open grassland alongside. Adjacent to the dead trees, mean species number/plot was reduced to seven (native 3.7) compared to open grassland (13.4; native 10.9). Mouse-eared hawkweed (Hieracium pilosella) was dominant in the open grassland plots and had very low cover inside the dead-tree plots. Grasses and native shrubs showed enhanced growth in the dead-tree plots. Average plant height was $21.3 \mathrm{~cm}$ compared to $5.4 \mathrm{~cm}$ in the open grassland plots. It is suggested that novel microsites and additional nutrients from the decaying trees gave a competitive advantage to some plants for a period of time.
\end{abstract}

Keywords: wildings, grassland, microsite, plant growth, invader, natives.

\section{INTRODUCTION}

In the high country of New Zealand pre-Polynesian beech and podocarp forests were changed to grassland and shrubland through a phase of extensive burning (Molloy et al. 1963; Molloy 1977). The short-tussock grassland was degraded by frequent burning, high stock numbers and browsing by rabbits (Oryctolagus cuniculus). Invading exotic herbaceous and woody species have changed the character of high-country grassland in many areas (O'Connor 1982; Rose et al. 1995). The unplanned spread of self-seeding conifers (mainly Pinus contorta, $P$. nigra, $P$. sylvestris, $P$. radiata, Larix decidua and Pseudotsuga menziesii) is currently a big problem facing those interested in conservation, landscape values and habitat protection in the South Island high country.

Models designed to predict the spread of wilding conifers (Ledgard \& Langer 1999; North \& Ledgard 2005) have been developed to improve the understanding and management of wilding spread in the high country. A wide range of operational practices for removing and killing pines has been devised. A decision-support system and guidelines for choosing the best removal method for specific situations is being produced (N.J. Ledgard, pers. comm.).

Success in removal of conifers should be judged not only by their absence from the landscape, but also from the ecological changes occurring in the vicinity of felled trees. The response of the system will depend on its initial status and the method used to kill the wildings. This study investigated the effects that dead conifers, felled and left on site, would have on the remaining vegetation. 


\section{Study site}

\section{METHODS}

The study was carried out at Mt Barker, near Lake Coleridge, Canterbury (Map260 K35 E 2397345 N 5760675). The site is located on the eastern side of the main divide of the New Zealand Southern Alps at an altitude of $620 \mathrm{~m}$ asl. Annual average temperature is $10.6^{\circ} \mathrm{C}$ with ground frosts on $100-110$ days of the year and annual precipitation approximately $907 \mathrm{~mm}$. The Tekapo soil is derived from a $35 \mathrm{~cm}$ thick loess layer over Greywacke Moraine Till. The dominant vegetation is unimproved short-tussock grassland dominated by hawkweeds (Hieracium spp.) and native and introduced grasses ((Festuca novae-zealandiae, Anthoxanthum odoratum, Agrostis capillaris). The area had been grazed for many decades, but was fenced from domestic stock grazing in 1992. Rabbit numbers have been low since the arrival of rabbit haemorrhagic disease in 1997.

In the selected area there were many scattered wilding pines (Pinus nigra; 50 trees/ha). In 1998 a number of trees estimated to be 12-15 years old were felled and left on site. This allowed direct comparison between vegetation developing in and around the dead stem and crown and the vegetation of grassland with no history of recent tree cover.

\section{Sampling design}

Five felled trees with adjacent open grassy areas were selected at random. A square sampling frame $(0.5 \times 0.5 \mathrm{~m})$ was placed in the crown area on either side of the dead tree's stem. Two identical frames were placed in the open area approximately $3 \mathrm{~m}$ away from the dead tree.

Present plant species were recorded by their percentage ground cover (visual estimate) in all plots. Species with less than 5\% cover were recorded only as 'present'. The average natural height of species (flower stalks excluded) was recorded by measuring at least three plants of each species present inside the plot.

\section{Data analysis}

Welch two sample t-test and the Wilcoxon test were used to compare open grassy plots and dead-tree plots on the basis of cover, height and species numbers per plot. Species were grouped into categories: native and exotic grasses, native herbs and grasses, exotic herbs and grasses, and native woody plants. Data transformations for plant species numbers per plot (square root transformation) and height data (log transformation) were used to normalise data. Statistical comparisons were carried out with the statistical software package R (Version 2.6.1).

\section{Vegetation cover}

\section{RESULTS}

The proportion of ground covered by vegetation was similarly high in the open plots $(94 \%)$ and dead-tree plots $(85 \%)(\mathrm{P}>0.05)$ (Table 1). Significant differences were found between cover of exotics and grasses $(\mathrm{P}<0.05)$. Exotic plants dominated the open plots $(50 \%)$, but only covered $14 \%$ of the plots inside the dead trees. Grass cover was greater $(\mathrm{P}<0.05)$ inside the dead-tree plots than in the open plots (Table 1). No significant difference was found between the cover of native species in the dead trees and in the open, or for woody plant species (Table 1).

TABLE 1: Ground cover (\%) of different vegetation categories within dead-tree plots and open grassland plots. Significance levels are given for t-tests. Values are the mean \pm standard error.

\begin{tabular}{lccc}
\hline Vegetation category & Dead-tree plots & Open grassland plots & Significance level \\
\hline Grass species & $62( \pm 5.4)$ & $26( \pm 4.6)$ & $\mathrm{P}<0.05$ \\
Native species & $62( \pm 6.4)$ & $52( \pm 5.1)$ & n.s. \\
Exotic species & $14( \pm 5.1)$ & $50( \pm 6.7)$ & $\mathrm{P}<0.05$ \\
Woody species & $16( \pm 5.3)$ & $11( \pm 4.4)$ & n.s. \\
Total & $85( \pm 4.6)$ & $94( \pm 4.4)$ & n.s. \\
\hline
\end{tabular}




\section{Plant height}

The average height of all vegetation and the height of individual vegetation categories differed between the dead-tree and open grassland plots. Average vegetation height (all species) was $21.3 \mathrm{~cm}$ in dead-tree plots and $5.4 \mathrm{~cm}$ in the open plots (Table 2). The average heights for both exotic $(13.3 \mathrm{~cm})$ and native $(27.7 \mathrm{~cm})$ plant species were four times higher in the dead-tree plots than in the open.

TABLE 2: Average height of plants $(\mathrm{cm})$ within dead-tree plots and in open grassland plots. Significance levels are given for t-test and Wilcoxontest. Values are the mean \pm standard error.

\begin{tabular}{lccc}
\hline Vegetation category & Dead-tree plots & Open grassland plots & Significance level \\
\hline Grass species & $29.7( \pm 1.7)$ & $11.1( \pm 2.0)$ & $\mathrm{P}<0.05^{1}$ \\
Native species & $27.7( \pm 1.5)$ & $5.7( \pm 0.7)$ & $\mathrm{P}<0.05$ \\
Exotic species & $13.4( \pm 1.9)$ & $3.6( \pm 0.4)$ & $\mathrm{P}<0.01$ \\
Woody species & $28.5( \pm 1.5)$ & $6.4( \pm 0.7)$ & $\mathrm{P}<0.01$ \\
Total & $21.3( \pm 0.9)$ & $5.4( \pm 0.6)$ & $\mathrm{P}<0.05$ \\
\hline
\end{tabular}

${ }^{1}$ Wilcoxon test was used here, because data were not normally distributed.

On average, the overall height of woody plants was 4.3 times higher in the dead-tree plots than in the open plots. Ozothamnus leptophyllus was found only in the dead-tree plots. A few small plants of this species were observed in the open, but outside the sample plots. In plots inside the dead trees, Discaria toumatou was $39 \mathrm{~cm}$ tall compared to only $9 \mathrm{~cm}$ in the open. A number of other woody species of naturally small habit, such as Leucopogon fraseri, were found in the open plots but were not observed inside the dead trees (Table 3). Individual grass plants were much taller in the dead-tree plots, where Festuca novae-zealandiae averaged $47 \mathrm{~cm}$ and Anthoxanthum odoratum $18.9 \mathrm{~cm}$, compared with $24 \mathrm{~cm}$ and $4.5 \mathrm{~cm}$ respectively in the open. The average height for all grasses was $30 \mathrm{~cm}$ in dead-tree plots and $11 \mathrm{~cm}$ in the open plots and the difference was statistically significant $(\mathrm{P}<0.05)$.

Species with the greatest ground cover were Festuca novae-zealandiae in the deadtree plots and Hieracium pilosella in the open grassland plots (Table 3). The exotic grass Anthoxanthum odoratum occurred frequently in the open plots (data not shown), but its contribution to cover was low (3.6\%), whereas in dead-tree plots its cover was higher $(11.7 \%)$. The proportion of grass cover (mainly natives) was much higher in dead-tree plots than in open plots (Table 3), even though the number of grass species was higher in the open (Table 4).

\section{Species number and composition}

More species per plot were found in the open (mean 13.4; range 9-22) than in the dead-tree plots (mean 7; range 6-9). The difference was due to the larger number of native species (11/open grassland plot) compared to 3.7/dead-tree plot (Table 4). The number of exotic species/plot was similar in both sets of plots ( $\mathrm{P}>0.05$; Table 4$)$. There were fewer woody species/plot in the dead trees than in the open (Table 4). 
TABLE 3: Mean ground cover $(\%)$ and height $(\mathrm{cm})$ of individual plant species within dead-tree plots and in open grassland plots. Numbers in brackets are the number of plots where species were found. Asterisks indicate native species.

\begin{tabular}{|c|c|c|c|c|}
\hline & \multicolumn{2}{|c|}{ Ground cover $(\%)$} & \multicolumn{2}{|c|}{ Plant height $(\mathrm{cm})$} \\
\hline & Dead-tree & Open & Dead-tree & Open \\
\hline \multicolumn{5}{|l|}{ Grasses } \\
\hline Agrostis capillaris & $6.1(2)$ & $0.6(1)$ & 8.2 & -- \\
\hline Anthoxanthum odoratum & $11.7(9)$ & $3.6(7)$ & 18.9 & 3.6 \\
\hline Carex sp. & $0.1(1)$ & -- & 0.3 & -- \\
\hline Elymus solandri* & $6.7(2)$ & -- & 7.1 & -- \\
\hline Festuca novae-zelandiae* & $32.2(8)$ & $16.7(8)$ & 41.9 & 21.9 \\
\hline Festuca rubra & $0.6(1)$ & -- & 2.8 & -- \\
\hline Graminae sp. & -- & $0.1(1)$ & -- & 1.7 \\
\hline Luzula rufa* & $1.2(3)$ & $0.3(3)$ & 3.8 & 1.0 \\
\hline Poa colensoi* & $3.9(2)$ & $3.7(7)$ & 8.9 & 7.9 \\
\hline Pyrrhanthera exigua* & -- & $1.2(7)$ & -- & 1.8 \\
\hline \multicolumn{5}{|l|}{ Shrubs } \\
\hline Coprosma petriei* & -- & $1.4(4)$ & -- & 1.0 \\
\hline Cyathodes colensoi* & $7.2(3)$ & $6.1(2)$ & 5.8 & 2.0 \\
\hline Discaria toumatou* & $5.1(4)$ & $1.1(6)$ & 17.7 & 6.4 \\
\hline Leucopogon fraseri* & -- & $1.3(8)$ & -- & 1.6 \\
\hline Muehlenbeckia auxillaris* & $0.1(1)$ & $0.7(2)$ & 0.6 & 0.2 \\
\hline Ozothamnus leptophyllus* & $3.9(2)$ & -- & 9.7 & -- \\
\hline Pimelia traversii $c f^{*}$ & $0.1(1)$ & $0.9(4)$ & 1.7 & 1.8 \\
\hline \multicolumn{5}{|l|}{ Herbs } \\
\hline Anisotome aromatica* & -- & $0.3(3)$ & -- & 0.7 \\
\hline Brachycome sinclairii* & -- & $0.4(4)$ & -- & 0.9 \\
\hline Celmisia gracilenta* & -- & $0.1(1)$ & -- & 0.2 \\
\hline Celmisia graminifolia* & -- & $1.0(5)$ & -- & 3.1 \\
\hline Gentiana corymbifera* & $0.2(2)$ & $0.8(7)$ & 1.9 & 1.9 \\
\hline Hieracium pilosella & $3.7(7)$ & $45.6(9)$ & 3.3 & 2.0 \\
\hline Hieracium praealtum & $0.9(4)$ & $0.8(3)$ & 4.8 & 1.0 \\
\hline Ourisia sessilifolia* & -- & $0.7(6)$ & -- & 1.3 \\
\hline Ranunculus mollis* & -- & $0.2(2)$ & -- & 0.2 \\
\hline Ranunculus sp.* & $0.2(2)$ & $0.3(3)$ & 0.6 & 0.7 \\
\hline Scleranthus uniflorus* & -- & $0.3(3)$ & -- & 0.7 \\
\hline Stellaria sp. & $0.7(2)$ & $0.1(1)$ & 4.7 & 1.1 \\
\hline Trifolium pratense & $3.6(5)$ & $0.1(1)$ & 5.6 & 0.2 \\
\hline Wahlenbergia albomarginata* & $0.7(2)$ & $0.3(3)$ & 0.4 & 0.7 \\
\hline \multicolumn{5}{|l|}{ Moss and Lichen } \\
\hline Cladonia sp.* & -- & $0.1(1)$ & -- & 0.2 \\
\hline Racomitrium crispulum* & -- & $14.4(9)$ & -- & 2.0 \\
\hline
\end{tabular}


TABLE 4: Average number of species and vegetation categories within dead-tree plots and in open grassland plots. Significance levels are given for t-test. Values are the mean \pm standard error.

\begin{tabular}{lccc}
\hline & Dead-tree & Open & Significance level \\
\hline Grasses & $3.1( \pm 0.3)$ & $4.1( \pm 1.5)$ & $\mathrm{P}<0.05$ \\
Native & $3.7( \pm 0.5)$ & $10.9( \pm 1.2)$ & $\mathrm{P}<0.05$ \\
Exotic & $3.2( \pm 0.2)$ & $2.5( \pm 0.3)$ & n.s. \\
Woody & $1.2( \pm 0.1)$ & $2.9( \pm 0.3)$ & $\mathrm{P}<0.05$ \\
Total & $7.0( \pm 0.3)$ & $13.4( \pm 1.5)$ & $\mathrm{P}<0.05$ \\
\hline
\end{tabular}

\section{DISCUSSION}

\section{Is the growth of grass species enhanced by the presence of dead trees?}

Native and exotic grass species showed increased vitality, as indicated by increased ground cover and increased plant height, inside dead trees. Grasses, especially Festuca novae-zealandiae and Anthoxanthum odoratum, appear to benefit from the environment associated with the remnants of dead pine trees. Development of these grasses appeared to suppress species of lower stature, e.g. Pyrrhanthera exigua and other short-tussock grassland species. This may account for the lower number of species found in the deadtree plots.

Does the presence of dead trees stimulate growth of woody species?

Although woody species, such as Discaria toumatou, Ozothamnus leptophyllus and Cyathodes colensoi, occurred in both dead-tree and open grassland plots, the habit and form of the plants differed. Shrubs were taller and appeared to be more vigorous when growing alongside the dead-trees. In the open their growth habit was low and close to the ground. Other woody species characteristic of the short-tussock grasslands, e.g. Coprosma petriei and Leucopogon fraseri, were not found in dead-tree plots. These low creeping shrubs may have been shaded out by the dense grass overstorey. The tallergrowing Discaria toumatou and Ozothamnus leptophyllus were able to develop in the presence of fast-growing grasses.

\section{Are exotic weeds disadvantaged by the presence of dead trees?}

Hieracium pilosella contributed little to plant cover in the dead-tree plots, but was the dominant species in open grassland plots. This plant is considered to be a threat to short-tussock grasslands because of its potential to outcompete native species for resources and space (Rose et al. 1995; Meurk et al.2002). Another hawkweed, Hieracium praealtum, was found in both sets of plots but less frequently than Hieracium pilosella. Other exotics found in greater abundance in the dead-tree than open plots were Trifolium pratense and the grasses Anthoxanthum odoratum and Agrostis capillaris. With the exception of Hieracium spp., numbers of exotic herbs were similar for both plot types. The comparison shows that a prostrate herb like Hieracium pilosella, with its ability to grow close to the ground, can dominate open grassland but is suppressed when taller grasses are present and growing well (Rose \& Frampton 1999).

\section{Limitations of the current study}

Evidence that the remains of dead trees promote the development of short-tussock grassland species is not yet fully conclusive. This investigation was restricted to one location, which is not representative of all sites where wilding pines are felled. Future studies in a wider range of sites will provide a more complete picture of vegetation dynamics, particularly over longer time frames, as there are indications that the positive effects of dead trees on plant growth may not persist for long periods.

Are dead and decaying pine trees beneficial to the restoration of degraded shorttussock grasslands?

To date, the main objective of wilding removal has been to prevent further spread of wilding trees. The present study indicates that there are also positive changes associated 
with the felling of wildings like the better development of grasses and native woody shrubs and the reduction of species like Hieracium pilosella. On the other hand this results in lower diversity, caused by the lack of lower prostrate species of the short-tussock grasslands. Other methods of wilding tree management, e.g. mulching and chemical spraying, are likely to have different outcomes. These are currently being studied as part of a Sustainable Farming Fund wilding project.

\section{ACKNOWLEDGMENT}

The authors gratefully acknowledge the assistance of MAF's Sustainable Farming Fund (Grant number 06/147). Without this support, the above work would not have been possible.

\section{REFERENCES}

Ledgard NJ, Langer ER 1999. Wilding Prevention Guidelines. NZ Forest Research Institute Ltd, Christchurch. 20 pp.

Meurk CD, Walker S, Gibson RS, Espie P 2002. Changes in vegetation states in grazed and ungrazed Mackenzie Basin grasslands, New Zealand, 1990-2000. New Zealand Journal of Ecology 26(2): 95-106.

Molloy BPJ 1977. The fire history. In: Burrows CJ ed. Cass. University of Canterbury, Christchurch, New Zealand. Pp. 157-170.

Molloy BPJ, Burrows CJ, Cox JE, Johnston JA, Wardle P 1963. Distribution of subfossil forest remains, eastern South Island, New Zealand. New Zealand Journal of Botany1: 68-77.

North H, Ledgard NJ 2005. Modelling wilding conifer spread and control. Report for Environment Canterbury, Scion, Christchurch, New Zealand. 27 pp.

O'Connor KF 1982. The implications of past exploitation and current developments to the conservation of South Island tussock grasslands. New Zealand Journal of Ecology 5: 97-107.

Rose AB, Frampton CM 1999. Effects of microsite characteristics on Hieracium pilosella seedling establishment in Marlborough tussock grasslands. New Zealand Journal of Botany 37: 107-118.

Rose AB, Platt KH, Frampton CM 1995. Vegetation change over 25 Years in a New Zealand short-tussock grassland: effects of sheep grazing and exotic invasions. New Zealand Journal of Ecology 19(2): 163-174. 